\title{
Influence of Bio-Fertilizers on Growth and Yield Attributing Attributes in Tomato
}

\author{
Barinderpal Singh $^{1 *}$, Kulbir Singh ${ }^{1}$, Dilpreet Talwar ${ }^{1}$, S.K. Jindal ${ }^{1}$ and V.S. Sardana ${ }^{2}$ \\ ${ }^{1}$ Department of Vegetable Science, Punjab Agricultural University, Ludhiana-141004, \\ Punjab, India \\ ${ }^{2}$ Department of Plant Breeding and Genetics, Punjab Agricultural University, \\ Ludhiana-141004, Punjab, India \\ *Corresponding author
}

\begin{tabular}{|c|}
\hline $\begin{array}{l}\text { Ke y w o r d s } \\
\text { Biofertilizers, } \\
\text { Azotobacter, } \\
\text { Azospirillum, Integrated } \\
\text { nutrient management }\end{array}$ \\
\hline Article Info \\
\hline $\begin{array}{l}\text { Accepted: } \\
30 \text { March } 2018 \\
\text { Available Online: } \\
10 \text { April } 2018\end{array}$ \\
\hline
\end{tabular}

\section{A B S T R A C T}

The investigation was conducted to study the effect of integrated nutrient management studies in tomato (Solanum lycopersicum L.). The cultivar Punjab Ratta and Punjab Varkha Bahar-4 comprised the plant material in autumn and rainy season, respectively. The experiment comprised fourteen treatments of biofertilizers and organic manures with or without chemical fertilizers. The experiment was conducted in randomized complete block design with three replications. The cultures of biofertilizers i.e. Azotobacter, Azospirillum and Phosphorus Solublizing Bacteria (PSB) were applied to the seedlings while Vesicular-Arbuscular Mycorrhizae (VAM) was applied directly in the treatment plots @ $500 \mathrm{~g} / \mathrm{ha}$. The treatment with Azotobacter was found beneficial for improving plant height, number of branches per plant and leaf area when it was applied along with recommended dose of fertilizers (RDF). Azotobacter along with VAM and RDF improves the number of branches per plant, leaf area, fruit diameter and number of fruits per plant. Likewise Azospirillum along with RDF and Azotobacter along with VAM and RDF helped to increase the fruit yield in rainy and autumn season to the tune of 549 and $543.1 \mathrm{q} \mathrm{ha}^{-1}$ which was $25 \%$ and $19.3 \%$ higher than the RDF respectively. The application of Azotobacter and Azospirillum along with $75 \%$ recommended dose of nitrogen during autumn season and Azotobacter, Azospirillum, PSB and VAM treatments along with $75 \%$ $\mathrm{N}$ and $75 \% \mathrm{P}$ of the recommended dose of nitrogen and phosphorus during rainy season recorded yield at par with RDF. It is concluded that Azotobacter along with VAM and 75 $\%$ dose of $\mathrm{N}$ and $\mathrm{P}$ saves the nitrogenous and phosphorus fertilizers without any significant reduction in yield. The application of Azotobacter along with VAM and recommended dose of N, P and K during autumn season and the application of Azospirillum along with recommended dose of fertilizers during rainy season proves beneficial for production of tomato under Punjab conditions.

\section{Introduction}

Tomato (Solanum lycopersicum L.) is an important nutritious vegetable crop of the world. Its fruits are consumed both as raw and in processed form. Tomato yield potential largely depends on various agronomic factors. Among these factors plant nutrition is 
important that affects growth and yield of tomato (Dumas et al., 2003). Tomato is a heavy feeder of nutrients and requires large quantities of chemical fertilizers (Samaila et al., 2011). Since last decade, tomato production has increased due to increased use of fertilizers and cultivation of high yielding varieties. Tomato crop consumed $280 \mathrm{~kg} \mathrm{~N}$, $55 \mathrm{~kg} \mathrm{P}_{2} \mathrm{O}_{5}$ and $540 \mathrm{~kg} \mathrm{~K}_{2} \mathrm{O} \mathrm{ha}^{-1}$ for producing 30t ha ${ }^{-1}$ (Akhtar et al., 2003). However excessive use of chemical fertilizers pollutes not only environment and underground water but also makes the soil acidic and reduces the soil fertility gradient. On the other hand high cost of chemical fertilizers makes crop production uneconomical for small and middle class farmers. Organic manures alone also cannot produce yield similar to chemical fertilizers (Heeb et al., 2006). Integration of biofertilizers with inorganic fertilizers at rates below those recommended for optimum tomato production may result in saving of inorganic fertilizers and sustain production (Taiwo et al., 2007). Therefore, the present investigation was planned and conducted to study the effect of biofertilizers on growth and yield attributes of tomato.

\section{Materials and Methods}

The study was conducted at vegetable research farm, Punjab Agricultural University, Ludhiana during the autumn and rainy season of 2015-16 to access the impact of different combinations of bio-fertilizer (Azotobacter, Azospirillium, VAM, PSB) along with inorganic fertilizers and organic manures (FYM) on growth and yield characters of tomato cultivars Punjab Ratta and Punjab Varkha Bahar-4 comprised the plant material in autumn and rainy season. The soil of the experimental field with loamy sand texture, good water holding capacity, $\mathrm{pH}$ of 7.6 and 7.4 (during autumn and rainy season respectively) and moderate soil fertility status. The fourteen treatments were replicated three times in randomized block design in $3.0 \mathrm{~m} \times$ $3.0 \mathrm{~m}$ plots. Full dose of inorganic phosphorus and potash was applied at the time of transplanting. Half of nitrogen was applied as basal and the remaining dose of $\mathrm{N}$ was applied 30 days after planting. Bio-fertilizer was applied on day of transplanting by seedling treatment except VAM which was mixed in soil. The crop was irrigated to avoid moisture stress. Plant height, number of branches per plant, leaf area, fruit diameter, fruit weight and fruit yield was measured. The fruits were harvested on maturity. The statistical analysis was done as per the standard procedure for analysis of variance for RCBD. Least significant difference was employed for mean comparison.

\section{Results and Discussion}

\section{Plant height (cm)}

During autumn season, after 30 days of transplanting (DAT), plant height attained with application of Azotobacter along with VAM and recommended dose of fertilizers $\left(\mathrm{T}_{9}\right)$ was significantly higher from the treatments where $75 \%$ dose of fertilizers was applied (Table 1). Plant height with recommended dose of fertilizers $\left(T_{13}\right)$ was statistically at par with all the recommended dose of fertilizers treatments along with biofertilizers and significantly higher with $75 \%$ dose of fertilizer treatments. At 60 DAT, maximum plant height was achieved in treatment with VAM along with recommended dose of fertilizers $\left(\mathrm{T}_{7}\right)$ that was $48.4 \mathrm{~cm}$ which was significantly higher from rest of treatments except treatments where PSB along with $75 \%$ dose of $\mathrm{P}$ and recommended dose of $\mathrm{N}$ and $\mathrm{K}$ was applied $\left(\mathrm{T}_{6}=46 \mathrm{~cm}\right)$ and Azotobacter along with VAM and 75\% dose of $\mathrm{N}$ and $\mathrm{P}\left(\mathrm{T}_{9}=47.2\right.$ $\mathrm{cm}$ ) (Table 1). Minimum plant height was attained in the treatment where no fertilizer was applied $\left(\mathrm{T}_{14}\right)$. At $90 \mathrm{DAT}$, application of 
Azotobacter along with recommended fertilizer dose $\left(T_{1}\right)$ resulted in maximum plant height $(67.2 \mathrm{~cm})$ which was significantly higher from attained with Azotobacter, Azospirillum along with $75 \quad \% \quad \mathrm{P}$ and recommended dose of $\mathrm{N}$ and $\mathrm{K}\left(\mathrm{T}_{2}\right.$ and $\left.\mathrm{T}_{4}\right)$ FYM alone or along with Azotobacter and VAM ( $\mathrm{T}_{11}$ and $\left.\mathrm{T}_{12}\right)$ and control $\left(\mathrm{T}_{14}\right)$ treatments (Table 1). Plant height in case of without application of fertilizers $\left(\mathrm{T}_{15}\right)$ was significantly lower than all treatments of biofertilizers along with recommended dose of $\mathrm{N}, \mathrm{P}$ and $\mathrm{K}$.

During Rainy season, plant height was recorded after 30, 60 and 90 days of transplanting (DAT), maximum plant height was recorded in $T_{1}$ treatment where Azotobacter along with recommended dose of inorganic fertilizers was applied and it was significantly higher from recommended dose of fertilizers $\left(\mathrm{T}_{13}\right)$ and control $\left(\mathrm{T}_{14}\right)$ treatments (Table 1). At 60 days of transplanting, plant height was significantly higher in treatment $T_{1}$ as compare to treatments where PSB and VAM biofertilizers along with $75 \%$ dose of $\mathrm{P}$ was applied $\left(\mathrm{T}_{6}\right.$ and $\left.\mathrm{T}_{8}\right)$ (Table 1$)$.

While at 90 days of transplanting, $\mathrm{T}_{1}$ treatment was significantly higher than that attained with PSB along with $75 \% \mathrm{P}$ and recommended dose of $\mathrm{N}$ and $\mathrm{K}\left(\mathrm{T}_{6}\right)$ and FYM along with Azotobacter and VAM $\left(\mathrm{T}_{11}\right)$.

Biofertilizers along with recommended dose of inorganic fertilizers recorded maximum plant height at 30, 60 and 90 DAT of transplanting as compared to treatments where $75 \%$ dose of inorganic fertilizers along with biofertlizers and where alone inorganic fertilizers treatment were applied due to the reason that bio-inoculums increase the nutrient fixation and make available to plant and increase production of growth promoting hormones which improves the vegetative growth of plant.
Optimum $\mathrm{N}$ application and fixation through Azotobacter and Azospirillum treatments resulted in production of carbohydrates and phytohormones which improve the plant growth. Similar results were notified by Talwar et al., (2016), Jayathilake et al., (2002) in bulbaceous crops. Similarly highest plant height $(65.1 \mathrm{~cm}$ and $63.9 \mathrm{~cm})$ were observed with treatment of Azotobacter and Azospirillum along with recommended dose of fertilizers in cauliflower (Singh and Singh 2005).

\section{Number of branches per plant}

In Autumn season, Maximum number of branches per plant (15.4) was observed with application of Azospirillum along with recommended dose of fertilizers $\left(\mathrm{T}_{3}\right)$ and Azotobacter along with VAM and recommended dose of fertilizers $\left(\mathrm{T}_{9}\right)$ and it was statically at par with treatments where PSB, VAM and Azotobacter along with VAM and $75 \%$ dose of inorganic fertilizers was applied $\left(\mathrm{T}_{5}, \mathrm{~T}_{6}, \mathrm{~T}_{8}\right.$, and $\left.\mathrm{T}_{10}\right)$ and was significantly at par with all other treatments (Table 1). While, in Rainy season, highest number of branches per plant (12.6) was recorded in $\mathrm{T}_{1}$ treatment where Azotobacter along with recommended dose of inorganic fertilizers was applied and it was significantly higher from all other treatments (Table 1).

More number of branches per plant was observed in treatment where biofertilizers applied along with recommended dose of fertilizers $\left(\mathrm{T}_{3}\right.$ and $\left.\mathrm{T}_{9}\right)$ as compared to control may be attributed to the production of growth promoting substances by biofertilizers.

The results are in line with Ramakrishnan and Selvakumar (2012) that highest number of branches per plant was recorded with application of Azospirillum or Azotobacter along recommended dose of inorganic fertilizers as compared to control. 
Table.1 Effect of different treatments on growth parameters in autumn and rainy seasons in tomato

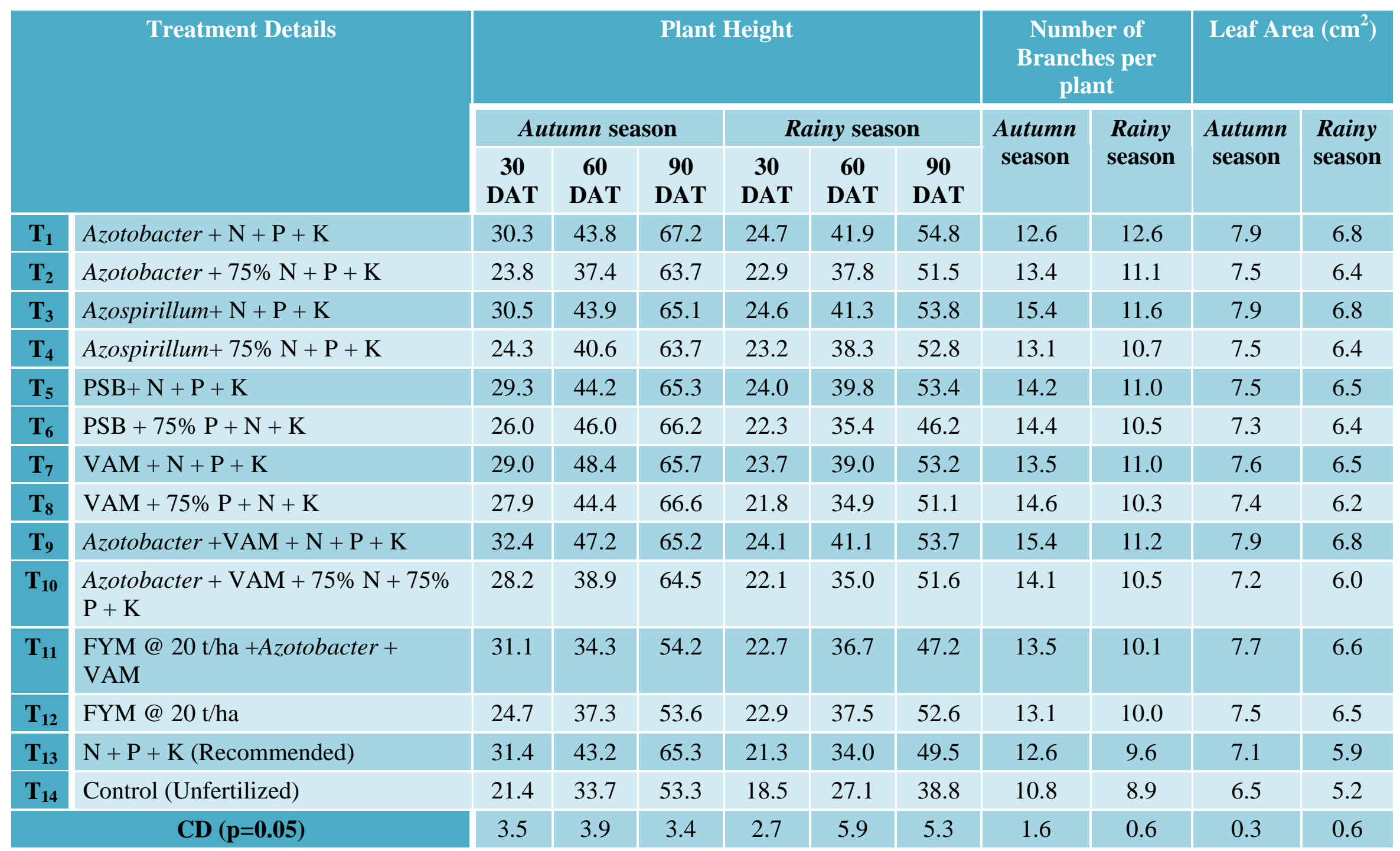

*RD: Recommended dose of fertilizers ( $150 \mathrm{~kg} / \mathrm{ha} \mathrm{N}, 62.5 \mathrm{~kg} / \mathrm{ha} \mathrm{P}, 62.5 \mathrm{~kg} / \mathrm{ha} \mathrm{K})$

** DAT: Days after transplanting 
Table.2 Effect of different treatments on fruit diameter $(\mathrm{cm})$, fruit weight $(\mathrm{g})$, number of fruits per plant and fruit Yield (q/ha) in tomato

\begin{tabular}{|c|c|c|c|c|c|c|c|c|c|}
\hline \multirow{2}{*}{\multicolumn{2}{|c|}{ Treatments }} & \multicolumn{2}{|c|}{$\begin{array}{l}\text { Fruit diameter } \\
\qquad(\mathrm{cm})\end{array}$} & \multicolumn{2}{|c|}{ Fruit weight (g) } & \multicolumn{2}{|c|}{$\begin{array}{c}\text { Number of fruits } \\
\text { per plant }\end{array}$} & \multicolumn{2}{|c|}{$\begin{array}{l}\text { Fruit yield } \\
\text { (q/ha) }\end{array}$} \\
\hline & & $\begin{array}{l}\text { Autumn } \\
\text { season }\end{array}$ & $\begin{array}{l}\text { Rainy } \\
\text { season }\end{array}$ & $\begin{array}{c}\text { Autumn } \\
\text { season }\end{array}$ & $\begin{array}{l}\text { Rainy } \\
\text { season }\end{array}$ & $\begin{array}{c}\text { Autumn } \\
\text { season }\end{array}$ & $\begin{array}{l}\text { Rainy } \\
\text { season }\end{array}$ & $\begin{array}{c}\text { Autumn } \\
\text { season }\end{array}$ & $\begin{array}{l}\text { Rainy } \\
\text { season }\end{array}$ \\
\hline $\mathbf{T}_{1}$ & Azotobacter $+\mathrm{N}+\mathrm{P}+\mathrm{K}$ & 4.7 & 5.4 & 73.2 & 94.7 & 37.0 & 35.2 & 529.0 & 528.9 \\
\hline $\mathbf{T}_{2}$ & Azotobacter $+75 \% \mathrm{~N}+\mathrm{P}+\mathrm{K}$ & 4.5 & 5.2 & 70.8 & 84.0 & 33.5 & 30.7 & 506.5 & 487.6 \\
\hline $\mathbf{T}_{3}$ & Azospirillum $+\mathrm{N}+\mathrm{P}+\mathrm{K}$ & 4.8 & 5.5 & 77.9 & 98.0 & 36.7 & 35.1 & 540.0 & 549.0 \\
\hline $\mathbf{T}_{4}$ & Azospirillum $+75 \% \mathrm{~N}+\mathrm{P}+\mathrm{K}$ & 4.4 & 5.2 & 68.3 & 85.3 & 32.9 & 31.3 & 507.4 & 491.4 \\
\hline $\mathbf{T}_{5}$ & $\mathrm{PSB}+\mathrm{N}+\mathrm{P}+\mathrm{K}$ & 4.5 & 5.3 & 77.9 & 90.7 & 35.1 & 31.8 & 524.7 & 514.7 \\
\hline $\mathbf{T}_{6}$ & $\mathrm{PSB}+75 \% \mathrm{P}+\mathrm{N}+\mathrm{K}$ & 4.4 & 5.2 & 73.4 & 79.7 & 33.4 & 26.6 & 507.8 & 486.3 \\
\hline $\mathbf{T}_{7}$ & $\mathrm{VAM}+\mathrm{N}+\mathrm{P}+\mathrm{K}$ & 4.5 & 5.3 & 73.8 & 89.0 & 36.2 & 31.7 & 530.6 & 493.9 \\
\hline $\mathbf{T}_{8}$ & $\mathrm{VAM}+75 \% \mathrm{P}+\mathrm{N}+\mathrm{K}$ & 4.3 & 5.1 & 64.9 & 77.7 & 35.1 & 29.0 & 504.8 & 484.8 \\
\hline $\mathbf{T}_{9}$ & Azotobacter $+\mathrm{VAM}+\mathrm{N}+\mathrm{P}+\mathrm{K}$ & 4.9 & 5.3 & 73.5 & 94.0 & 38.1 & 34.5 & 543.1 & 506.9 \\
\hline $\mathbf{T}_{10}$ & Azotobacter $+\mathrm{VAM}+75 \% \mathrm{~N}+75 \% \mathrm{P}+\mathrm{K}$ & 4.5 & 5.2 & 71.9 & 82.7 & 33.5 & 29.5 & 514.7 & 484.4 \\
\hline $\mathbf{T}_{11}$ & FYM@20 t/ha +Azotobacter+VAM & 4.5 & 5.2 & 76.0 & 80.7 & 30.2 & 33.3 & 526.2 & 514.6 \\
\hline $\mathbf{T}_{12}$ & FYM@20 t/ha & 4.6 & 5.3 & 72.5 & 84.7 & 30.1 & 27.5 & 482.0 & 472.5 \\
\hline $\mathbf{T}_{13}$ & $\mathrm{~N}+\mathrm{P}+\mathrm{K}$ (Recommended) & 4.2 & 4.9 & 66.6 & 86.5 & 33.8 & 27.0 & 469.2 & 461.1 \\
\hline $\mathbf{T}_{14}$ & Control (Unfertilized) & 3.6 & 4.5 & 56.3 & 61.7 & 23.7 & 21.1 & 383.4 & 389.4 \\
\hline & $\mathrm{CD}(\mathrm{p}=0.05)$ & 0.4 & 0.3 & 4.8 & 12.1 & 4.3 & 5.7 & 24.3 & 35.1 \\
\hline
\end{tabular}

*RD: Recommended dose of fertilizers ( $150 \mathrm{~kg} / \mathrm{ha} \mathrm{N}, 62.5 \mathrm{~kg} / \mathrm{ha} \mathrm{P}, 62.5 \mathrm{~kg} / \mathrm{ha} \mathrm{K})$ 
Maximum number of branches per plant was recorded with application of combined treatment of biofertilizers along with recommended dose of inorganic fertilizers as compare to alone Azotobacter or Azospirillium treatment due to tomato plants inoculated with combination of BiofertilizerVAM and Azospirillum/Azotobacter fixed more nitrogen (Tilak, 1995).

\section{Leaf area $\left(\mathrm{cm}^{2}\right)$}

Leaf area is used to predict photosynthetic primary (compound) production, evapotranspiration and as a reference tool for crop growth. Leaf area plays an essential role in theoretical production ecology (Wilhelm et al., 2000).

In Autumn season, leaf area in treatments with Azotobacter, Azospirillum along with recommended dose of $\mathrm{N}, \mathrm{P}$ and $\mathrm{K}\left(\mathrm{T}_{1}\right.$ and $\left.\mathrm{T}_{3}\right)$ and Azotobacter along with VAM and recommended dose of fertilizers $\left(\mathrm{T}_{9}\right)$ was significantly higher from all treatments except $\mathrm{T}_{7}$ and $\mathrm{T}_{11}$ (Table 1). While, in Rainy season, maximum Leaf area $\left(6.8 \mathrm{~cm}^{2}\right)$ was recorded with $\mathrm{T}_{1}, \mathrm{~T}_{3}$ and $\mathrm{T}_{9}$ which was significantly higher than that attained with Azotobacter along with VAM and $75 \%$ dose of $\mathrm{N}, \mathrm{P}$ and recommended dose of $\mathrm{K}\left(\mathrm{T}_{10}\right)$, recommended dose of fertilizers $\left(\mathrm{T}_{13}\right)$ and control treatment $\left(\mathrm{T}_{14}\right)$ where no fertilizer was applied (Table $1)$.

Highest leaf area was recorded with application of Azotobacter and Azospirillum due to higher plant height and greater number of photosynthetically active compounds in leaves per palnt, which were enhanced by the production of bioactive substances having similar effects as that of growth regulators besides nitrogen fixation through bacterial fertilizers. The results are in line with Shashi and Manoj (2012) that maximum leaf area index $\left(3.41 \mathrm{~cm}^{2}\right)$ was recorded with the application of Azotobacter along with recommended dose of fertilizers which was significantly higher from the control and inorganic fertilizer alone treatments.

\section{Fruit diameter $(\mathbf{c m})$}

Tomato fruit diameter is an important parameter in promoting the yield potential of the crop. Fruit diameter has strong and positive correlation with the fruit weight suggesting that the increased individual fruit size is fundamental to maximize tomato yield productivity per unit area.

In Autumn season, application of Azotobacter along with VAM and recommended dose of $\mathrm{N}, \mathrm{P}$ and $\mathrm{K}\left(\mathrm{T}_{9}\right)$ resulted in maximum fruit diameter $(4.9 \mathrm{~cm})$ that was significantly higher than that attained with $\mathrm{T}_{4}(4.4 \mathrm{~cm}), \mathrm{T}_{6}$ $(4.4 \mathrm{~cm}), \mathrm{T}_{8}(4.3 \mathrm{~cm})$ and $\mathrm{T}_{13}(4.2 \mathrm{~cm})$ and was statistically at par with rest of the treatments (Table 2). In Rainy season (cm) maximum fruit diameter $(5.5 \mathrm{~cm})$ was recorded in $\mathrm{T}_{3}$ treatment which was statistically at par with all other treatments except $\mathrm{T}_{8}$ (5.1), $\mathrm{T}_{13}$ (4.9) and control (4.5) treatments (Table 1). Regardless of the rate, $\mathrm{N}$ fertilization along with Azospirillum during rainy season increased fruit diameter by about $13 \%$ in reference to the control. This was in agreement with Nasreen et al., (2007). The results are in conformity with the findings Meena et al., (2014) significant higher fruit diameter of tomato was recorded with application of Azospirillum $(6.58 \mathrm{~cm})$.

\section{Average fruit weight (g)}

In Autumn season, maximum fruit weight (Table 2) of tomato was recorded in the treatment $\mathrm{T}_{3}$ where Azospirillium along with recommended dose of fertilizers and $T_{5}$ treatment where PSB along with recommended dose of fertilizers was applied (77.9 g). Similarly in Rainy season, maximum 
fruit weight $(98.0 \mathrm{~g})$ was recorded with application of Azospirillium along with recommended dose of fertilizers $\left(\mathrm{T}_{3}\right)$. In both the seasons, maximum fruit weight attained treatments was significantly higher from all treatments where $75 \%$ dose of recommended dose of fertilizers was applied $\left(\mathrm{T}_{2}, \mathrm{~T}_{4}, \mathrm{~T}_{8}\right.$ and $\mathrm{T}_{10}$ ) and from $\mathrm{T}_{13}$ (recommended dose of fertilizer treatment) and $\mathrm{T}_{14}$ (Control) treatments (Table 2).

This might be due to essential effects of biofertilizers that enhances the root development, improves the nutrient uptake potential of roots and to some extent ability of nitrogen fixation (Okon and Itzigsohn 1995). The results are in line with Ramakrishnan and Selvakumar (2012) that with the combined application of Azotobacter and Azospirillum average fruit weight of tomato $(25.36 \mathrm{~g})$ was significantly improved as compare to dose of fertilizers $(18.34 \mathrm{~g})$. Similar results were recorded by Meena et al., (2014) that highest fruit weight was recorded with application of Azospirillum $(70.24 \mathrm{~g})$ as compare to PSB $(64.16 \mathrm{~g})$ or recommended dose of fertilizer $(33.76 \mathrm{~g})$ treatment alone.

\section{Number of fruits per plant}

In Autumn season, fruits per plant were directly related with fruit yield. More the number of fruits per plant there will be more yield of tomato. The data reveals that maximum number of fruits per plant (38.1) was obtained with application of Azotobacter along with VAM and recommended dose of fertilizers $\left(\mathrm{T}_{9}\right)$ was applied and it was significantly higher than that recorded with all treatments where $75 \%$ dose of recommended dose of fertilizers was applied $\left(T_{2}, T_{4}, T_{6}\right.$ and $\mathrm{T}_{10}$ ) and from all organic manure treatments $\left(\mathrm{T}_{11}\right.$ and $\left.\mathrm{T}_{12}\right)$ and from control treatment $\left(\mathrm{T}_{14}\right)$ and was statistically at par with all other treatments (Table 2). In Rainy season, maximum number of fruits per plant (35.2) was obtained with application of $\mathrm{T}_{1}$ treatment which was significantly higher than treatment $\mathrm{T}_{6}, \mathrm{~T}_{8}, \mathrm{~T}_{12}, \mathrm{~T}_{13}$ and $\mathrm{T}_{14}$ (control) and was statistically at par with all other treatments (Table 2).

The results are in conformity with Hossain and Mohanty (1999) and Gupta and Sengar (2000) that increase in yield of tomato with application of biofertilizers due to increase in number of fruits per plant and average fruit weight. The results are in line with Meena et al., (2014) where treatment of Azospirillum produces maximum number of fruits per plant as compare to control in tomato. This might be due to reason that with application of biofertilizers, considerable amounts of biologically active substances like B vitamins, nicotinic acid, pantothenic acid, biotin, heteroxins, gibberellins etc. are produced which improves the growth of plants and significantly improves number of fruits per plant.

\section{Fruit yield (q/ha)}

Tomato yield is an important growth contributing parameter. Yield represents the benefit or losses from the crop.In Autumn season, the perusal of data showed that maximum fruit yield was recorded with Azotobacter along with VAM and recommended dose of fertilizers $\left(T_{9}\right)$ was statically at par with application of $\mathrm{T}_{1}(529 \mathrm{q}$ $\left.\mathrm{ha}^{-1}\right)$ and $\mathrm{T}_{3}\left(540 \mathrm{q} \mathrm{ha}^{-1}\right), \mathrm{T}_{5}\left(524.7 \mathrm{q} \mathrm{ha}^{-1}\right), \mathrm{T}_{7}$ $\left(530.6 \mathrm{q} \mathrm{ha}^{-1}\right), \mathrm{T}_{11} \quad\left(526.2 \mathrm{q}^{\mathrm{h}} \mathrm{ha}^{-1}\right)$ and significantly higher from rest of treatments (Table 2). While, in Rainy season, highest fruit yield $(549.0 \mathrm{q} / \mathrm{ha})$ was recorded in $\mathrm{T}_{3}$ treatment where Azospirillum along with recommended dose of fertilizers was applied and it was significantly more from rest of treatments except $T_{1}$ (Azotobacter along with $\mathrm{RDF}$ ), $\mathrm{T}_{5}$ (PSB along with RDF) and $\mathrm{T}_{11}$ (FYM along with Azotobacter and VAM) treatments. 
Results are in conformity with Ramakrishnan and Selvakumar (2012) that maximum tomato yield was observed in biofertilizers (518.4 q/ha) followed by Azotobacter (502.2 q/ha) as compared to Azospirillum (492.1 q/ha) and control treatment. The results are in line with the results of Nanthakumar and Veeraraghavathatham (2000) in brinjal, Govindarajan and Thangaraju (2001) in chilli and Talwar et al., (2016) in onion. Meena et al., (2014) observed that highest tomato fruit yield was recorded with Azospirillum (363.6 $\mathrm{q} / \mathrm{ha}$ ) treatment as compare to PSB (317.5 $\mathrm{q} / \mathrm{ha}$ ) and control treatment ( $241.5 \mathrm{q} / \mathrm{ha})$. This might be due to with application of biofertilizer, secretion of ammonia also enhanced in the rhizosphere, which enhance the nutrient uptake potential of plant and improve the fruit yield. Azospirillum also produce plant growth regulatory substances which stimulate plant growth and yield.

It is concluded from the present investigation that Azospirillum along with RDF and Azotobacter along with VAM and RDF improves the growth and yield attributing parameters of tomato. Azotobacter, Azospirillum treatments along with $75 \%$ dose of $\mathrm{N}$ and PSB or VAM treatments along with $75 \%$ dose of $\mathrm{P}$ recorded the tomato yield statistically at par with the yield obtained with RDF which saves $25 \%$ nitrogen and phosphorus fertilizers during rainy season. The present investigation encourage the use of biofertilizers along with organic and inorganic fertilizers for sustainable tomato production.

\section{References}

Akhtar, M. E., Khan, M. Z., Rashid, M. T., Ahsan, Z., and Ahmad, S. (2003) Effect of potash application on yield and quality of tomato (Lycopersicon esculentum L.). Pakistan Journal of Botany 42: 1695-1720.
Dumas, Y., Dadomo, M., Lucca, G. D. and Grolier, P. (2003) Effects of environmental factors and agricultural techniques on antioxidant content of tomatoes. Journal of Science Food and Agriculture 83: 369-82.

Govindarajan, K., and Thangaraju, M. (2001) Azospirillum - a potential inoculant for horticultural crops. South Indian Horticulture 49: 233-35.

Gupta, C. R., and Sengar, S. S. (2000) Response of tomato (Lycopersicon esculentum Mill.) to nitrogen and potassium fertilization in acidic soil of Bastar. Vegetable Science 27: 94-95.

Heeb, A., Toor, R., and Savage, K. (2006) Influence of different types of fertilisers on the major antioxidant components of tomatoes. Journal of Food and Drug Analysis 19: 20-27.

Hossain, M. M., and Mohanty, B. K. (1999) Studies on the effects of nitrogen and potash on the performance of tomato cv. Punjab Chhuhara. Orissa Journal of Horticulture 27: 44-47.

Jayathilake, P. K. S., Reddy, I. P., Srihari, D., and Reddy, R. (2002) Effect of nutrient management on growth, yield and yield attributes of rabi onion (Allium cepa L.). Vegetable Science 29: 184-85.

Meena, R. K., Kumar, S., Maji, S., Kumar, D., and Kumar, M. (2014) Effect of organic manures and biofertilizers on growth, yield and quality of tomato cv. Pusa Sheetal. International Journal of Agricultural Sciences 10: 329-32.

Nanthakumar, S., and Veeraraghavathatham, D. (2000) Effect of integrated nutrient management on growth parameters and yield of brinjal (Solanum melongena L.) cv. PLR-1. South Indian Horticulture 48: 31-35.

Nasreen, S., Haque, M. M., Hossain, M. A., Farid, A. T. M. (2007) Nutrient uptake and yield of onion as influenced by nitrogen and sulphur fertilization. 
Bangladesh Journal of Agricultural Research 32: 413-20.

Okon, Y., Itzigsohn, R. (1995) The development of Azospirillum as a commercial inoculant for improving crop yields. Biotechnology Advances 13: 415-24.

Ramakrishnan, K., and Selvakumar, G. (2012) Effect of biofertilizers on enhancement of growth and yield on Tomato (Lycopersicum esculentum Mill.). International Journal of Botany and Research 2: 20-23.

Samaila, A., Amans, E. B., Abubakar, I. U., Babaji, B. A. (2011) Nutritional quality of tomato (Lycopersicon esculentum L.) as influenced by mulching, nitrogen and irrigation interval. Journal of Agricultural Sciences 3: 266-70.

Shashi, K., and Manoj, R. (2012) Effect of biofertilizers on growth and yield of tomato (Lycopersicon esculentum Mill). Progressive Horticulture 39: 2249-58.

Singh, V. N., and Singh, S. S. (2005) Effect of inorganic and biofertilizers on production of cauliflower (Brassica oleraea L. var. botrytis). Vegetable Science 32: 146-49.

Taiwo, L. B., Adediran, J. A., and Sonubi, O. A. (2007) Yield and quality of tomato grown with organic and synthetic fertilizers. Vegetable Science 13: 5-19.

Talwar, D., Singh, K., Sardana, V. and Singh, J. (2016) Growth, yield and quality of onion as influenced by integrated nutrient management. International Journal of Agricultural Sciences 8: 2295-98.

Tilak, K. V. B. R. (1995) Vesiculararbuscular myccorhizae and Azospirillum brailiense rhizocoenosis in tomato and peal millet intercropping system in semi-arid tropics In: Adholeya A\& S. Singh (Eds.) Proceedings of Third National Conference on Mycorrhiza (pp. 177179). Tata Energy Research Institute, New Delhi.

Wilhelm, W. W., Ruwe, K., and Schlemmer, M. R. (2000) Comparisons of three Leaf Area Index Meters in a Corn Canopy. Crop Science 40: 1179-83.

\section{How to cite this article:}

Barinderpal Singh, Kulbir Singh, Dilpreet Talwar, S.K. Jindal and Sardana, V.S. 2018. Influence of Bio-Fertilizers on Growth and Yield Attributing Attributes in Tomato. Int.J.Curr.Microbiol.App.Sci. 7(04): 3686-3694. doi: https://doi.org/10.20546/ijcmas.2018.704.414 